\title{
TTR
}

Traduction, terminologie, rédaction

Marc Charron, Seymour Mayne and Christiane Melançon.

Pluriel : Une anthologie, des voix/An Anthology of Diverse

Voices. Ottawa, Presses de l'Université d'Ottawa, 2008, 284 p.

\section{Catherine Khordoc}

Volume 23, numéro 2, 2e semestre 2010

URI : https://id.erudit.org/iderudit/1009167ar

DOI : https://doi.org/10.7202/1009167ar

Aller au sommaire du numéro

Éditeur(s)

Association canadienne de traductologie

ISSN

0835-8443 (imprimé)

1708-2188 (numérique)

Découvrir la revue

Citer ce compte rendu

Khordoc, C. (2010). Compte rendu de [Marc Charron, Seymour Mayne and Christiane Melançon. Pluriel : Une anthologie, des voix/An Anthology of Diverse Voices. Ottawa, Presses de l'Université d'Ottawa, 2008, 284 p.] TTR, 23(2),

225-227. https://doi.org/10.7202/1009167ar d'utilisation que vous pouvez consulter en ligne.

https://apropos.erudit.org/fr/usagers/politique-dutilisation/ 


\section{Marc Charron, Seymour Mayne and Christiane Melançon. Pluriel: Une anthologie, des voix/An Anthology of Diverse Voices. Ottawa, Presses de l'Université d'Ottawa, 2008, 284 p.}

There are many reasons to celebrate the publication of this anthology of Canadian and Québécois poetry. All fifty-eight poems appear in their original French or English, accompanied by a translation in Canada's other official language on the facing page. Some of the poems, especially the ones written in French, appear in translation for the first time, and therefore will be discovered by Anglophone readers who are not as familiar with Québécois poetry. It is also significant that this anthology publishes poetry written by immigrant writers side-by-side with non-immigrant writers as well as pieces by First-Nations poets. The themes that bring together these poems are plurality and diversity, certainly ones that are quite dominant in what is often called "ethnic," "minority" or "migrant" writing, but it is refreshing that we are reminded that they are not exclusive to writers who have experienced immigration or exile first-hand. Indeed, Canadian-born writers in addition to those who have been displaced without immigrating are also preoccupied by the question of the "Other" as well as the cultural, linguistic, sexual and physical diversities that characterize not only Canadian society but the globalized world. Thus, it is truly wonderful to read the poetry of Nadine Ltaif alongside that of Gérald Leblanc and Robert Dickson in the same volume that also includes poems by Margaret Atwood, A.M. Klein, Rienzi Crusz and Armand Garnet Ruffo (to name only a few examples), as well as to be able to read them in French or in English, or both, of course.

However, the fact that these themes are so broad also presents a certain difficulty. It is not clear what motivated the choices made by the editors. If the common thread is the inscription of alterity, what of the poems that were excluded? Is the "Other" in all of its possible configurations not characteristic of most poetic writing? While I do not dispute the choice of poems that are included in this anthology, I do wonder about what was not included. For example, Marco Micone's poem "Speak What" is clearly a suitable poem to have included, but Michèle Lalonde's "Speak White" that Micone pastiches is not included, and yet 
its questioning of alterity is undisputable. Because the number of poems included in this anthology is limited (this is not a "Norton" style anthology of 500+ pages!), it would be helpful to understand why certain poets and why certain pieces were or were not included. The English-language preface does explain that the editors followed their "own tastes and interests," which, in matters of poetry, is perhaps a sound way to proceed, though it does leave some questions unanswered. More significantly, the editors hope to create "some dialogue or echoing among the texts [to] help shape a convergence of voices, no matter the language of the original poem" (p. 10). They do achieve this in many ways; most notably, the inclusion of poetry by "migrant" writers (for lack of a better word) in French and English does bring out some of the similarities in their experiences and attempts to integrate or help shape Canada's and Québec's cultural landscape.

The volume includes in fact two prefaces, one in French and one in English, and they are not merely translations of the same text. It is in fact surprising to find that the two prefaces are indeed quite different, and I recommend to readers that they read both if possible. The French preface in particular develops to a greater degree the issues of plurality and diversity in Canadian poetry, while the English preface, a shorter text, limits itself to editorial comments. "Canadian poetry" in fact does not exist, according to the French-language preface, but rather there are "des poésies au Canada" (p. 5) and this anthology certainly testifies to this statement.

The fact that these poems are reprinted along with a translated version engages another dimension of plurality. Many of the poems are themselves multilingual, presenting further complications for translators; for example, how to translate into English a French-language poem that includes English or how the dominance of English or the foreign-ness of another language is rendered in translation. This is accomplished in different ways, sometimes using italics, like in Gérald Leblanc's "Éloge du chiac," translated by Donald Winkler, but without explanation for the use of italics. Occasionally the original French expressions remain in the translated poem, like in Salvador Torres Saso's "En défense de la langue," also translated by Winkler, which is probably the 
most satisfying option. Or, in A.M. Klein's poem, "Montreal," translated by Charlotte and Robert Melançon, gallicized words in the English original are anglicized in the French, rendering the atmosphere created in the poem whose hybridized language is an integral part of the city that inspires it. Some of the poems were translated specifically for the purposes of this anthology, and while it can only be positive that these poems are now available to Francophone and Anglophone readers, this does sometimes result in an uneven quality in the translated poems, which in some cases seem to privilege the "literal" and not always the "poetic." This is a minor quibble, however, and overall this volume is an important contribution to Canadian and Québécois literary studies and to poetry in general.

\section{Catherine Khordoc Carleton University}

Antoine Berman. L'Âge de la traduction. "La tâche du traducteur " de Walter Benjamin, un commentaire. Texte établi par Isabelle Berman avec la collaboration de Valentina Sommella. Saint-Denis, Presses Universitaires de Vincennes, coll. "Intempestives ", 20081.

\section{Cahier $5^{2}$}

Découvrir des «affinités électives » entre les langues ne se résout pas à un exercice comparatif balayant leurs propriétés morphologiques respectives pour y détecter l'empreinte d'un blueprint ancestral dont l'ascendant attesterait la parenté originaire des idiomes ornant l'œkoumène terrestre et que l'on aurait le loisir de cartographier, par exemple, à l'aide d'un schéma à progression arborescente. Benjamin n'est pas partisan d'une pensée généalogique. Il fait plutôt valoir un principe de convergence de portée ontologique qui touche à l'essence même du langage et qui engage la traduction à cet égard. Mais il va plus

1 Cité désormais $A T$.

2 Ceci est la deuxième de trois parties de ce compte rendu. Pour la première partie, v. TTR, 23, 1, pp. 210-258. 